\title{
Experimental induction of bacterial kidney disease in chinook salmon by immersion and cohabitation challenges
}

\author{
C. B. Murray, T. P. T. Evelyn, T. D. Beacham, L. W. Barner, J. E. Ketcheson, \\ L. Prosperi-Porta
}

Department of Fisheries and Oceans, Biological Sciences Branch, Pacific Biological Station, Nanaimo, British Columbia, Canada V9K 5K6

\begin{abstract}
Two challenge methods for inducing bacterial kidney disease (BKD), caused by Renibacterium salmoninarum (Rs), in salmon were evaluated using chinook salmon Oncorhynchus tshawytscha. The first method involved immersing the fish in various concentrations of Rs cells $\left(10^{4}\right.$ to $\left.10^{6} \mathrm{ml}^{-1}\right)$ for 15 or $30 \mathrm{~min}$ (the immersion method); the second method was based on the enforced cohabitation of uninfected fish with others that had been injected intraperitoneally with various doses $\left(10^{3}, 10^{5}\right.$, and $\left.10^{7}\right)$ of Rs cells (the cohabitation method). Both methods were successful in establishing BKD in the test fish but, as expected with this slow-acting pathogen, the challenges took considerable time to complete. With the immersion method, a 2 -fold increase in exposure time and a 100 -fold increase in pathogen concentration did not significantly affect the mean time to death of the fish (ca 203 d; average water temperature $12.6^{\circ} \mathrm{C}$ ). However, mortalities at 180 and $305 \mathrm{~d}$ post challenge were dose-related. With the cohabitation method, mean time to death in the non-injected fish was $145 \mathrm{~d}$; fish that had been injected with $10^{3}, 10^{5}$, and $10^{7}$ Rs cells and that served as the source of the infection for the non-injected fish had mean times to death of 60,83 , and $104 \mathrm{~d}$, respectively (average water temperature $9.9^{\circ} \mathrm{C}$ ). The advantages and disadvantages of the challenge methods are discussed.
\end{abstract}

\section{INTRODUCTION}

Bacterial kidney disease (BKD), caused by Renibacterium salmoninarum (Rs), is a chronic and often fatal disease of salmonids. The causative agent is a fastidious, slow-growing, non-motile, Gram-positive bacterium (Fryer \& Sanders 1981). It can be transmitted horizontally (Mitchum \& Sherman 1981, Bell et al. 1984, Austin \& Rayment 1985), and vertically via the egg (Bullock et al. 1978, Evelyn et al. 1984, 1986). The disease can cause servere losses among intensively cultured salmonids (Bullock \& Herman 1988), and in British Columbia (B. C.) Canada, where salmon are farmed to a large size before marketing, it is the most important infectious disease problem faced by the salmon farming industry.

Control of BKD is difficult to achieve. Chemotherapy provides only temporary benefit, and a vaccine effective against the disease has yet to be developed (Elliott et al. 1989). Control measures for BKD are therefore largely limited to avoidance of the causative agent.
However, in B. C., control by this approach is difficult to accomplish because the pathogen is widely enzootic in the province (Evelyn 1988).

The ideal solution to the BKD problem would be to develop a vaccine effective against the disease (Elliott et al. 1989) or to use salmonid species or strains that possess relatively high levels of innate BKD resistance (Withler \& Evelyn 1990). Unfortunately, a generally acceptable challenge method for evaluating anti-BKD vaccines or for selecting resistant strains of salmonids appears to be lacking. Challenge methods used to date have included injection, ingestion, hyperosmotic and direct immersion, and cohabitation (Bell et al. 1984, Elliott et al. 1989), with the most widely adopted method being injection. Injection, however, bypasses the natural skin and mucous barriers of the fish. In addition, there has been a tendency to use challenge levels that produce complete mortality within 20 to $50 \mathrm{~d}$ (McCarthy et al. 1984, Austin 1985, Kaattari et al. 1986, Sakai et al. 1989). In our experience, this is considerably faster than the natural progression of the disease 
and likely overwhelms any advantages possessed by the fish as a result of vaccination or due to their innate BKD resistance.

Immersion (McCarthy et al. 1984, Kaattari et al. 1986) and cohabitation (Bell et al. 1984, Evelyn 1988) have shown promise as BKD challenge methods and they represent a more natural route of challenge than injection. The present study was therefore undertaken to examine the feasibility of using immersion and cohabitation as methods for inducing BKD in chinook salmon (Oncorhynchus tshawytscha).

\section{MATERIALS AND METHODS}

Experimental fish. Chinook salmon gametes for the immersion challenges were obtained from the Nitinat River Hatchery (west coast of Vancouver Island, B. C.); chinook salmon gametes for the cohabitation challenges were obtained from Big Qualicum River (east coast of Vancouver Island) chinook salmon reared to maturity in net pens at the Pacific Biological Station. The eggs for both experiments were fertilized, surfacedisinfected with 100 ppm iodine for $15 \mathrm{~min}$, and incubated at the Pacific Biological Station in vertical stack incubators supplied with dechlorinated Nanaimo municipal water. Nitinat fry (immersion challenges) were reared in 351 tanks supplied with dechlorinated fresh water and maintained on an appropriate sized commercial diet until they reached a weight of 4.0 (SE 0.06) g. Big Qualicum fry (cohabitation challenges) were reared in $1000 \mathrm{l}$ tanks supplied with dechlorinated and ultraviolet light-treated fresh water and fed an appropriate sized commercial diet, The Big Qualicum fish were immersion-vaccinated against Vibrio anguillarum, $V$. ordalii, and Aeromonas salmonicida when they reached $3.5 \mathrm{~g}$. When these fish reached
$10.0 \mathrm{~g}$, they were gradually introduced to ambient ultraviolet light-treated $30 \%$ sea water over a 2 wk period. The Big Qualicum fish were sampled for Rs and found to be free of the pathogen: in the 3 mo preceding the cohabitation experiment, the kidneys of 63 fish dying in this population were examined for Rs by the indirect fluorescent antibody technique (Bullock \& Stuckey 1975) and found to be Rs-free. Water samples taken directly after the ultraviolet light sterilizer were aIso found to be pathogen-free. The Big Qualicum fish were challenged by the cohabitation method (see 'Challenge methods') when they reached a weight of 48.9 (SE 0.52) g.

Challenge bacterium. The bacterium used for challenging the fish was Rs: isolate 384 . The hacterium was initially obtained from a cultured chinook salmon, dead of bacterial kidney disease (Evelyn et al. 1986) and its virulence was maintained by passage through juvenile salmon and storage at $-85^{\circ} \mathrm{C}$. Suspensions of the pathogen, used for the challenges, consisted of $\log$ phase cells, grown at $15^{\circ} \mathrm{C}$ for 12 d on KDM-2 medium (Evelyn 1977) and suspended in cold, sterile peptonesaline $(0.1 \% \mathrm{w} / \mathrm{v}$ peptone $+0.85 \% \mathrm{w} / \mathrm{v} \mathrm{NaCl})$ to a turbidity of $1.25 \mathrm{OD}$ at $540 \mathrm{~nm}$. This suspension was mixed with suitable volumes of fresh water (immersion challenge) or peptone-saline (cohabitation challenge) to obtain the challenge doses desired. Counts of viable cells in the challenge suspensions were made using the methods outlined by Evelyn et al. (1989).

Challenge methods. Challenge by immersion was accornplished by immersing 40 fish for 15 or $30 \mathrm{~min}$ in 11 of challenge suspension containing $3.0 \times 10^{4}, 3.0 \times$ $10^{5}$, or $3.0 \times 10^{6} \mathrm{Rs}$ cells $\mathrm{ml}^{-1}$ (Table 1 ). Two replicates were used for each challenge level and duration. Two tanks (40 unchallenged fish tank ${ }^{-1}$ ) were maintained as controls. The controls were included mainly to indicate that the experimental population did not carry a

Table 1. Oncorhynchus tshawytscha. Treatment (cells $\mathrm{ml}^{-1}$ and duration), percent mortality, and mean time to death in days for Nitinat River chinook salmon challenged with Renibacterium salmoninarum by immersion. N: number of fish challenged. Standard deviations are in parentheses. Note: there was no significant effect of challenge concentration or duration on mean time to death at 180 or $350 \mathrm{~d}$ post challenge

\begin{tabular}{|c|c|c|c|c|c|}
\hline \multirow[t]{2}{*}{ Treatment } & \multirow[t]{2}{*}{$N$} & \multicolumn{2}{|c|}{$180 \mathrm{~d}$ post challenge } & \multicolumn{2}{|c|}{$350 \mathrm{~d}$ post challenge } \\
\hline & & $\begin{array}{c}\% \\
\text { mortality }\end{array}$ & $\begin{array}{l}\text { Mean time to } \\
\text { death }\end{array}$ & $\begin{array}{c}\% \\
\text { mortality }\end{array}$ & $\begin{array}{l}\text { Mean time to } \\
\text { death }\end{array}$ \\
\hline $\begin{array}{l}3.0 \times 10^{4}, 15 \mathrm{~min} \\
3.0 \times 10^{4}, 30 \mathrm{~min}\end{array}$ & $\begin{array}{l}40 \\
80\end{array}$ & $\begin{array}{l}5.0 \\
5.0\end{array}$ & $\begin{array}{l}100.5(27.58\} \\
118.7(39.84)\end{array}$ & $\begin{array}{l}15.0 \\
13.7\end{array}$ & $\begin{array}{lr}201.0 & (153.34) \\
218.1 & (85.33)\end{array}$ \\
\hline $\begin{array}{l}3.0 \times 10^{5}, 15 \mathrm{~min} \\
3.0 \times 10^{5}, 30 \mathrm{~min}\end{array}$ & $\begin{array}{l}80 \\
80\end{array}$ & $\begin{array}{l}18.7 \\
12.5\end{array}$ & $\begin{array}{r}100.8(42.24) \\
95.9(46.29)\end{array}$ & $\begin{array}{l}50.0 \\
31.2\end{array}$ & $\begin{array}{lr}205.5 & (91.12) \\
207.1 & (103.05)\end{array}$ \\
\hline $\begin{array}{l}3.0 \times 10^{6}, 15 \mathrm{~min} \\
3.0 \times 10^{6}, 30 \mathrm{~min}\end{array}$ & $\begin{array}{l}80 \\
80\end{array}$ & $\begin{array}{l}20.0 \\
22.5\end{array}$ & $\begin{array}{rr}105.7 & (42.62) \\
93.4 & (36.29)\end{array}$ & $\begin{array}{l}50.0 \\
42.5\end{array}$ & $\begin{array}{ll}210.3 & (97.53) \\
173.4 & (97.21)\end{array}$ \\
\hline Control & 80 & 0.0 & & 0.0 & \\
\hline
\end{tabular}


background Rs infection or acquire a new Rs infection during the experiment. After challenge, the fish were reared in $35 \mathrm{l}$ tanks and fed a commercial diet of the appropriate size. One replicate challenged with $3.0 \times$ $10^{4}$ Rs cells $\mathrm{ml}^{-1}$ for 15 min was lost due to a disruption of the water supply shortly after the challenge. At $180 \mathrm{~d}$ post challenge, the control and challenged fish were transferred to larger tanks and then gradually converted to sea water. During transfer, the fish from both control replicates were anaesthetized, handled, and put in one $2400 \mathrm{l}$ tank. Also, the challenged fish were anaesthetized, fin-clipped to identify the treatment received, and put in another $2400 \mathrm{l}$ tank. Conversion from fresh water to ambient untreated $30 \%$ sea water took place over a $1 \mathrm{wk}$ period beginning on Day 180 post challenge. The experiment was terminated at 350 $\mathrm{d}$ post challenge, and during the challenge period water temperatures averaged $12.6^{\circ} \mathrm{C}$.

Challenge by cohabitation was accomplished by holding 3 groups of deliberately infected fish (50 fish group $^{-1}$ ) in a $1000 \mathrm{l}$ tank containing 50 non-infected fish (subsequently termed crossovers). Three challenge levels were used to ensure a continuous source of challenge for the crossover fish. Ten replicates with 150 injected and 50 non-injected fish in each tank were used. Fish in the deliberately infected groups were injected intraperitoneally with $0.1 \mathrm{ml}$ of peptone-saline containing either $1.0 \times 10^{3} \mathrm{Rs}_{\text {cells } \mathrm{fish}^{-1}}$ (Group 1), 1.0 $\times 10^{5}$ cells fish ${ }^{-1}$ (Group 2), or $1.0 \times 10^{7} \mathrm{Rs}$ cells fish ${ }^{-1}$ (Group 3). All groups of fish in the tank were uniquely cold-branded to identify them as to treatment received. Water temperatures during the cohabitation challenge averaged $9.9^{\circ} \mathrm{C}$.

Autopsy protocol. In the immersion and cohabitation challenges 30 and $80 \%$ of the mortalities, respectively, were examined to confirm the cause of death. For this purpose, kidney tissue samples were aseptically taken, cultured on tryptic soy agar, and used for preparing Gram-stained smears. Rs was diagnosed as the cause of death if the smears contained large numbers of small Gram-positive rods, if the rods failed to grow on tryptic soy agar at $21{ }^{\circ} \mathrm{C}$, and if the smears $10 \%$ of them checked) proved positive for Rs using a commercially available anti-Rs serum (Microtek) in the indirect fluorescent antibody technique (Bullock \& Stuckey 1975).

Analyses. The immersion and cohabitation experiments were evaluated by calculating the mortality rates and the mean times to death for each treatment and replicate. Preliminary analysis of the data from the immersion and cohabitation experiments indicated no significant differences among replicates for a given treatment; therefore the replicates for a given treatment were combined for further analysis. In both challenge experiments, mortality rates were compared by using the likelihood ratio or $G$-test, and mean time to death was $\log _{\mathrm{e}}$-transformed to make the variance independent of the mean (Sokal \& Rohlf 1981). Variation in mean time to death for the immersion experiment was analyzed with a 2-way analysis of variance model, with challenge concentration and challenge duration as the indices. Variation in mean time to death for the cohabitation experiment was analyzed with a 1-way analysis of variance model, with treatment ( 3 challenged groups and one crossover group) as the index.

\section{RESULTS}

\section{Autopsies}

All of the kidney smears from 50 immersion, 1332 deliberately infected, and 500 crossover mortalities contained short Gram-positive bacilli typical of Rs. Cultures from the sampled fish failed to grow on tryptic soy agar at $21{ }^{\circ} \mathrm{C}$, and the pathogen was present in randomly selected kidney smears stained by the Rsspecific immunofluorescent technique. We therefore concluded that all of the mortalities observed in both challenge experiments were caused by Rs.

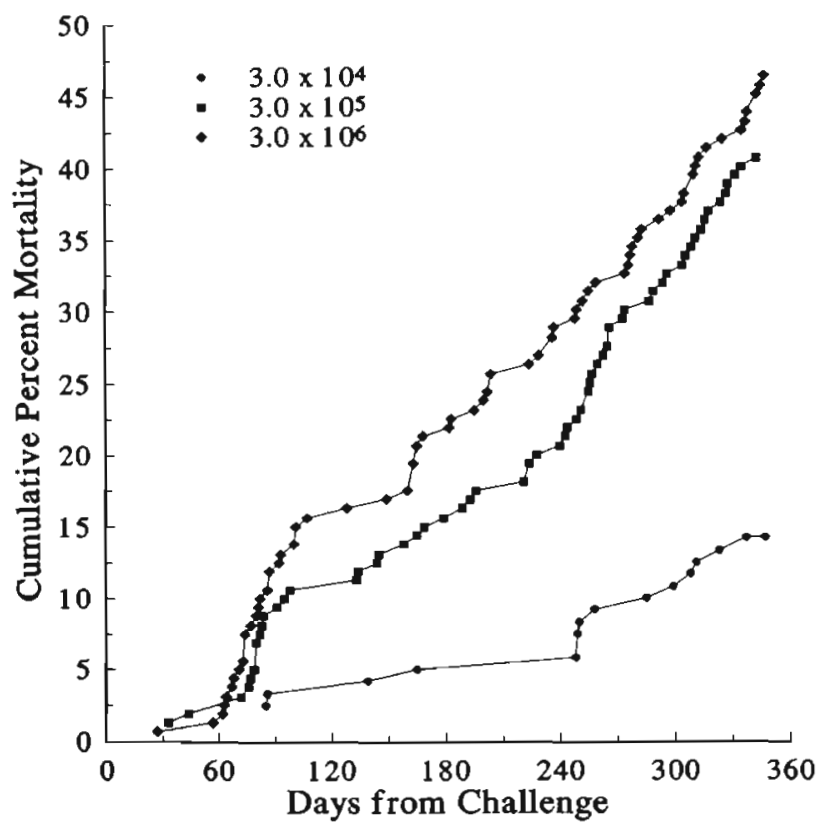

Fig. 1. Oncorhynchus tshawytscha. Cumulative percent mortality for Nitinat River chinook salmon challenged by immersion in $3.0 \times 10^{4}(\mathrm{~N}=120$ fish $), 3.0 \times 10^{5}(\mathrm{~N}=160$ fish $)$, and $3.0 \times 10^{6}(\mathrm{~N}=160$ fish) Renibacterium salmoninarum cells $\mathrm{ml}^{-1}$. Fish challenged on March 1, 1989 and experiment terminated on February 15, 1990 (350 d post challenge). Fresh water ranged from 6.5 to $18.4^{\circ} \mathrm{C}$ for the first $180 \mathrm{~d}$ and sea water ranged from 8.2 to $14.4^{\circ} \mathrm{C}$ for the remaining $170 \mathrm{~d}$ 


\section{SurvivaI}

Mortalities in the immersion experiment began at 27 to $85 \mathrm{~d}$ post challenge, depending on challenge received, and continued until the experiment was terminated at 350 d post challenge (Fig. 1). Mortalities in the immersion experiment were significantly different after 350 d post challenge between challenge durations at $3.0 \times 10^{5}$ Rs cells $\mathrm{ml}^{-1}(G=5.11$; $\mathrm{df}=1$; $\mathrm{p}<0.05)$, but not between challenge durations at $3.0 \times 10^{4}$ or 3.0 $\times 10^{6} \mathrm{Rs}$ cells $\mathrm{ml}^{-1}$ (Table 1 ). Because there were no consistent trends in mortalities associated with challenge durations, we combined the mortalities within each challenge concentration. Mortalities in the freshwater phase of the immersion experiment (180 d post challenge) were similar at $3.0 \times 10^{6} \mathrm{Rs}$ cells $\mathrm{ml}^{-1}$ $(21.2 \%)$ and $3.0 \times 10^{5} \mathrm{Rs}$ cells $\mathrm{ml}^{-1}(15.6 \%)$, but significantly lower $(5.0 \%)$ at $3.0 \times 10^{4} \mathrm{Rs}_{\text {cells ml }}^{-1}(G$ $=17.55 ; \mathrm{df}=2 ; \mathrm{p}<0.05$ ) (Fig. 1). Mortalities after 170 $\mathrm{d}$ in sea water (350 d post challenge) increased to 46.2 . 40.6 , and $15.4 \%$ at $3.0 \times 10^{6}, 3.0 \times 10^{5}$, and $3.0 \times 10^{4}$ Rs cells $\mathrm{ml}^{-1}$, respectively, with mortalities at $3.0 \times 10^{6}$ and $3.0 \times 10^{5} \mathrm{Rs}$ cells $\mathrm{ml}^{-1}$ being similar to each other but significantly higher than those at $3.0 \times 10^{4}$ Rs cells $\mathrm{ml}^{-1}(G=37.21$; df $=2 ; \mathrm{p}<0.05)$. There was no significant effect of challenge concentration or duration on

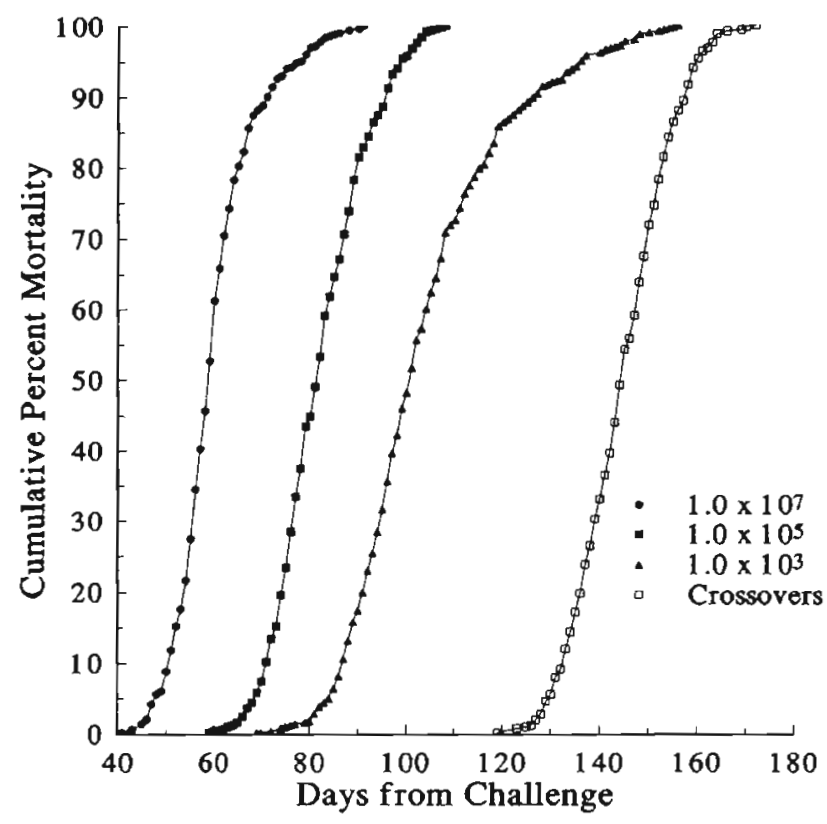

Fig. 2. Oncorhynchus tshawytscha. Cumulative percent mortality for Big Qualicum chinook salmon challenged by cohabitation with chinook salmon injected intraperitoneally with $1.0 \times 10^{3}, 1.0 \times 10^{5}$, and $1.0 \times 10^{7}$ Renibacterium salmoninarum cells fish $^{-1}$ The challenge dose received by the crossover fish is not known. There were 500 fish in each treatment. Fish challenged on January 28, 1988 and experiment terminated on July 18,1988 (172 d post challenge). Sea

water ranged from 8.3 to $11.9^{\circ} \mathrm{C}$ during the experiment mean time to death after 180 or 350 d post challenge. Mean time to death for all challenges was $100.3 \mathrm{~d}$ at $180 \mathrm{~d}$ post challenge and $202.6 \mathrm{~d}$ at $350 \mathrm{~d}$ post challenge.

Mortality curves in the cohabitation experiment were clearly distinct and related to the challenges received (Fig. 2). In the injected fish, mortalities began on 41,59 , and $69 \mathrm{~d}$ post challenge and reached $100 \%$ on 91,108 and $156 \mathrm{~d}$ with $1.0 \times 10^{7}, 1.0 \times 10^{5}$, and $1.0 \times 10^{3} \mathrm{Rs}$ cells fish $^{-1}$, respectively. Mortalities in the crossover fish began on Day 119 and reached $100 \%$ on Day 172 post challenge (Fig. 2). Mean time to death was 60.2, 82.5 , and $104.1 \mathrm{~d}$ for challenged fish injected with $1.0 \times$ $10^{7}, 1.0 \times 10^{5}$, and $1.0 \times 10^{3}$ Rs cells fish $^{-1}$, respectively, and $145.0 \mathrm{~d}$ for crossnver fish. Mean time to death for the various challenges were significantly different from each other $(F=5035.9$; df $=3$, 1996; $\mathrm{p}<0.05$ )

\section{DISCUSSION}

Our data indicate that challenge methods based on immersion and cohabitation can be used for establishing $R$ s infections in chinook salmon. These challenge methods obviously have the disadvantage of taking considerable time to complete (Bell et al. 1984, McCarthy et al. 1984) - perhaps because only a few cells of the slow-growing bacterium manage to enter the fish when administered by these methods. The advantage, however, of these challenge methods is that they result in a subtle challenge that is not likely to overwhelm minor differences in BKD resistance that might occur among different groups of fish. In addition, unlike challenge by injection (which also imposes the additional stress of handling each individual fish), they more closely simulate the natural routes of infection because none of the natural barriers to infection in the fish is bypassed. Thus, if either of these challenge methods for evaluating innate or vaccine-induced resistance to $\mathrm{BKD}$ is used, any advantages in resistance that might be conferred on the fish by virtue of its integument will not likely be overlooked.

In the immersion challenge, mortality rate proved to be a better indicator of the challenge dose received than mean time to death. Our results would suggest that to achieve a mortality rate high enough to permit conclusions as to the survival merits of a particular treatment within a reasonable but realistic period of 4 to $6 \mathrm{mo}$, challenge suspensions should contain at least $10^{6} \mathrm{Rs}$ cells $\mathrm{ml}^{-1}$ (assuming exposure times of 15 to 30 min). Differences among treatments for mean time to death in our immersion challenge were not detected because of the high variance in mean time to death. The high variance in mean time to death was probably 
due to high variability in susceptibility of individual fish within this population. The lack of a dose-related response in mean time to death in the immersionchallenged fish was unexpected and needs to be investigated further. On the other hand, the lack of any effect of exposure duration on mortality rate was not too surprising because the exposure times varied only 2 -fold. It is possible that more effective immersion challenges could be achieved by increasing the duration of exposure to Rs. The cohabitation challenge method is an extreme example of what can be accomplished using prolonged exposure. Interestingly, no increase in death rate occurred as a result of transferring the immersion-challenged fish from fresh to sea water. Perhaps the reduced density resulting from the transfer to larger seawater tanks compensated for any stress associated with being held in sea water.

A desirable feature of the immersion challenge is that it is easy to standardize. In addition, if the immersionchallenged fish in a given tank represent different treatment groups (e.g. vaccinated and unvaccinated fish), the challenge method permits the determination of whether significant crossover infections between the groups are occurring. To accomplish this, unchallenged sentinel fish can be added to the tank (following the challenge) to measure the crossover infection rate. The main disadvantage of the immersion challenge is that it requires more inoculum to accomplish the challenge than any of the other challenge procedures. This becomes an important consideration when the challenge pathogen is difficult to mass produce, as is the case with Rs. Immersion challenge with Rs might be ruled out if large-scale experiments are involved.

The results of the cohabitation challenge confirm those of Bell et al. (1984) who suggested that experimentally-induced horizontal transmission might be developed into an acceptable challenge method for Rs. Bell et al. (1984) used sockeye salmon (Oncorhynchus nerka) in fresh water; we used chinook salmon in sea water. The technique therefore appears to be applicable to different species of salmonids, and the infectivity of Rs appears to remain intact in both fresh and sea water. Infectivity in sea water has been recognized by some workers (Evelyn 1988). Bell et al. (1984) found that the mortality curves for sockeye salmon challenged by inoculation with Rs and by crossover from the inoculated fish were clearly distinct and that the mean times to death were 53.6, 79.0, and $98.1 \mathrm{~d}$ at $5.7 \times 10^{3}, 5.7 \times 10^{5}$, and $5.7 \times 10^{7}$ Rs cells per inoculated fish, respectively, and $127.1 \mathrm{~d}$ for the fish infected by crossover. Using rather similar challenge doses, we observed the same thing but the mean times to death were slightly longer.

In the cohabitation challenge, the challenge dose received by the crossover fish is unknown. In addition, no assessment of crossover infections between variously treated groups being held in the same tank is possible because the challenge is a continuous one. These disadvantages of the cohabitation technique are, however, of minor importance in the case of Rs because the dosage appears to simulate what happens under fish culture conditions. Also, with a slowly developing disease like BKD the effect of crossover infections between the variously treated fish would be minimal if the experiment is stopped as soon as significant differences in mortality begin to occur between treatments. The procedure has the advantage over the immersion challenge in requiring only small amounts of inoculum, and although on the basis of the present experiment the cohabitation challenge appeared expensive in terms of the proportion of fish used to effect it ( $75 \%$ of the fish were used as the infection source), we now recognize that perfectly satisfactory challenges can be accomplished when only $5 \%$ of the fish serve as the source of the infection (Beacham \& Evelyn unpubl.).

Acknowledgements. We thank the managers and personnel of the Nitinat River Hatchery and the Pacific Biological Station Fish Farm for the chinook salmon gametes. The assistance of Andrew Enyvari, Jeanine Stacey, and Patricia Treherne in fish rearing and diagnostic duties is greatly appreciated.

\section{LITERATURE CITED}

Austin, B. (1985). Evaluation of antimicrobial compounds for the control of bacterial kidney disease in rainbow trout, Salmo gairdneri Richardson. J. Fish Dis. 8: 209-220

Austin, B., Rayment, J. N. (1985). Epizootiology of Renibacterium salmoninarum, the causal agent of bacterial kidney disease in salmonid fish. J. Fish Dis. 8: 505-509

Bell, G. R., Higgs, D. A., Traxler, G. S. (1984). The effect of dietary ascorbate, zinc, and manganese on the development of experimentally induced bacterial kidney disease in sockeye salmon (Oncorhynchus nerka). Aquaculture 36: 293-311

Bullock, G. L., Herman, R. L. (1988). Bacterial kidney disease of salmonid fishes caused by Renibacterium salmoninarum. U. S. Fish Wildl. Serv. Fish Dis. Leaflet 78

Bullock, G. L., Stuckey, H. M. (1975). Fluorescent antibody identification and detection of the Corynebacterium causing kidney disease in salmonids. J. Fish. Res. Bd Can. 32: 2224-2227

Bullock, G. L., Stuckey, H. M., Mulcalhy, D. (1978). Corynebacterial kidney disease: egg transmission following iodophore disinfection. Fish Health News 7: 51-52

Elliott, D. G., Pascho, R. J., Bullock, G. L. (1989). Developments in the control of bacterial kidney disease of salmonid fishes. Dis. aquat. Org. 6: 201-215

Evelyn, T. P. T (1977). An improved growth medium for the kidney disease bacterium and some notes on using the medium. Bull. off. Int. Epizoot. 87: 511-513

Evelyn, T. P. T (1988). Bacterial kidney disease in British Columbia, Canada: comments on its epizootiology and on methods for its control on fish farms. In: AQUA NOR 87 Trondheim International Conference. Norske Fiskeopp- 
dretternes Forening-Fiskeoppdretternes Salgslag A/L, Trondheim, Norway, p. 51-57

Evelyn, T P. T., Bell, G. R., Prosperi-Porta, L., Ketcheson, J. E. (1089). A simple technique for accelerating the growth of the kidney disease bacterium Renibacterium salmoninarum on a commonly used culture medium (KDM.2). Dis. aquat. Org. $7: 231-234$

Evelyn, T P. T., Prosperi-Porta, L., Ketcheson, J. E. (1984). The salmonid egg as a vector of the kidney disease bacterium, Renibacterium salmoninarum. In: ACUIGRUP (ed.) Fish diseases, $4^{\text {th }}$ COPRAO Session. Editora ATP, Madrid, p. $111-117$

Evelyn, T P. T., Prosperi-Porta, L., Ketcheson, J. E. (1986). Experimental intra-ovum infection of salmonid eggs with Renibacterium salmoninarum and vertical transmission of the pathogen with such eggs despite their treatment with erythromycin. Dis. aquat. Org. 1: 197-202

Fryer, J. L., Sanders, J. E. (1981). Bacterial kidney disease of sáimonid fishes. Ann. Rev. Mícrobiol. 35: 273-298

Kaattari, S., Blaaustein, K., Turaga, P., Irwin, M., Weins, G. (1986). Development of a vaccine for bacterial kidney

Editorial responsibility: Managing Editor disease in salmon. Annual Report for 1985 U. S. Dept. Energy Bonneville Power Admin. Div. Fish Wildl.

McCarthy, D. H., Croy, T. R., Amend, D. F. (1984). Immunization of rainbow trout, Salmo gairdneri Richardson, against bacterial kidney disease: preliminary efficacy evaluation. J. Fish Dis. 7: 65-71

Mitchum, D. L., Sherman, L. E. (1981). Transmission of bacterial kidney disease from wild to stocked hatchery trout. Can. J. Fish. Aquat. Sci. 38: 547-551.

Sakai, M., Atsuta, S., Kobayashi, M. (1989). Attempted vaccination of rainbow trout Oncorhynchus mykiss against bacterial kidney disease. Bull. Jap. Soc. scient. Fish. 55: 2105-2109

Sokal, R. R., Rohlf, F. J. (1981). Biometry. The principles and practice of statistics in biological research, 2 nd edn. W. H. Freeman and Co., San Francisco

Withler, R. E., Evelyn, T. P. I (1990). Genetic variation in resistance to bacterial kidney disease within and between two strains of coho salmon trom British Columbia. Trans. Am. Fish. Soc. 119: 1003-1009

Manuscript first received: May 13,1991 Revised version accepted: October 9, 1991 